\title{
Inhibitory effect of receptor for advanced glycation end products (RAGE) on the TGF- $\beta$-induced alveolar epithelial to mesenchymal transition
}

\author{
Jeong Sup Song ${ }^{1,5}$, Chun Mi Kang ${ }^{1}$, \\ Chan Kwon Park', Hyung Kyu Yoon', \\ Sook Young Lee ${ }^{2}$, Joong Hyun Ahn ${ }^{3}$ \\ and Hwa-Sik Moon ${ }^{4}$

\section{${ }^{1}$ Department of Internal Medicine \\ Yeouido St. Mary's Hospital} \\ The Catholic University of Korea, School of Medicine \\ Seoul 150-713, Korea \\ ${ }^{2}$ Department of Internal Medicine \\ Seoul St. Mary's Hospital \\ The Catholic University of Korea, School of Medicine \\ Seoul 137-701, Korea \\ ${ }^{3}$ Department of Internal Medicine \\ Inchun St. Mary's Hospital \\ The Catholic University of Korea, School of Medicine \\ Inchun 403-720, Korea \\ ${ }^{4}$ Department of Internal Medicine \\ St. Paul's Hospital \\ The Catholic University of Korea, School of Medicine \\ Seoul 130-709, Korea \\ ${ }^{5}$ Corresponding author: Tel, 82-2-3779-1146; \\ Fax, 82-2-780-3132; E-mail, jssong @ catholic.ac.kr \\ http://dx.doi.org/10.3858/emm.2011.43.9.059 \\ Accepted 5 July 2011 \\ Available Online 11 July 2011
}

Abbreviations: AEC, alveolar epithelial cell; AGE, advanced glycation end products; $\alpha$-SMA, alpha smooth muscle actin; ATII, alveolar type II epithelial cell; EMT, epithelial to mesenchymal transition; HMGB1, high mobility group box chromosomal protein 1; IPF, idiopathic pulmonary fibrosis; RAGE, receptor for advanced glycation end products

\begin{abstract}
Idiopathic pulmonary fibrosis (IPF) is a lethal parenchymal lung disease characterized by myofibroblast proliferation. Alveolar epithelial cells (AECs) are thought to produce myofibroblasts through the epithelial to mesenchymal transition (EMT). Receptor for advanced glycation end products (RAGE) is a member of the immunoglobulin superfamily of cell surface receptors whose activation is associated with renal fibrosis during diabetes and liver fibrosis. RAGE is ex-
\end{abstract}

pressed at low basal levels in most adult tissues except the lung. In this study, we evaluated the interaction of ligand advanced glycation end products (AGE) with RAGE during the epithelial to myofibroblast transition in rat AECs. Our results indicate that AGE inhibited the TGF- $\beta$-dependent alveolar EMT by increasing Smad7 expression, and that the effect was abolished by RAGE siRNA treatment. Thus, the induction of Smad7 by the AGE-RAGE interaction limits the development of pulmonary fibrosis by inhibiting TGF- $\beta$-dependent signaling in AECs.

Keywords: advanced glycosylation end-product receptor; epithelial-mesenchymal transition; glycosylation end products, advanced; pulmonary fibrosis; Smad7 protein

\section{Introduction}

Receptor for advanced glycation end products (RAGE), which specifically binds advanced glycation end products (AGE), is a member of the immunoglobulin superfamily of cell surface receptors (Neeper et al., 1992). RAGE was initially identified and characterized based on its ability to bind AGE adducts formed by glycoxidation, which accumulate in disorders such as diabetes (Schmidt et al., 1992). Since then, RAGE has been shown to be a pattern recognition receptor that recognizes several ligands, including amphoterins (commonly known as high mobility group box chromosomal protein, HMGB1) (Hori et al., 1995), S100/calgranulins (Hofmann et al., 1999), amyloid beta peptide and beta fibrils (Yan et al., 1996), and Mac-1 (Chavakis et al., 2003).

RAGE is expressed at a low basal level in most healthy adult tissues, except the lungs (Brett et al., 1993). RAGE expression increases whenever its ligands accumulate, and the interaction of RAGE with its ligand promotes the progression of several non-pulmonary diseases, including diabetic nephropathy, diabetic atherosclerosis, and neurodegenerative disorders (Brownlee et al., 1988; Schmidt et al., 2000, 2001; Morcos et al., 2002). The binding of AGE, S100/calgranulins, and HMGB1 to RAGE on vascular endothelial cells, neuronal cells, smooth muscle cells, or inflammatory cells may activate a 
Brain Heart Lung Kidney Liver

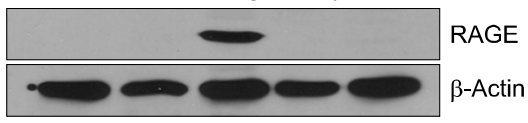

Figure 1. Rat organ homogenates were prepared and analyzed the RAGE expression by Western blot analysis. RAGE expression was predominantly high in the lung compared with other tissues.

range of signaling pathways, including those involving ERK1/2 MAP kinase, p38 and SAPK/JNK MAP kinase, rho GTPase, PI-3 kinase, and JAK/STAT, as well as the downstream activation of NF-kB (Kislinger et al., 1999; Huang et al., 2001; Yeh et al., 2001).

The role of RAGE in the pathogenesis of idiopathic pulmonary fibrosis (IPF) is controversial (Bargagli et al., 2009) as the loss of RAGE contributes to the pathogenesis of IPF, which is involved in the regulation of the migration and proliferation of fibroblasts and other cells (Englert et al., 2008; Queisser et al., 2008). RAGE also contributes to bleomycin-induced lung fibrosis (He et al., 2007; Hamada et al., 2008). RAGE over-expression is evident in areas of active fibrosis, including fibroblastic foci (Morbini et al., 2006). IPF is characterized by a sequence of events that begins with alveolar epithelial micro-injuries followed by the formation of fibroblastic foci and results in an exaggerated deposition of extracellular matrix that drives the destruction of the lung parenchymal architecture (Selman and Pardo, 2003).

Although RAGE is highly expressed in the lung compared to other tissues, few studies have examined its role in the alveolar epithelial to mesenchymal transition (EMT), which is proposed to play a central role in the development of pulmonary fibrosis. AGE has been shown to play a role in renal tubular EMT in diabetic nephropathy; however, the interaction of AGE with RAGE in the lung EMT has not been investigated. Therefore, we investigated the AGE-RAGE interaction in the development of alveolar EMT using isolated rat alveolar type II epithelial (ATII) cells.

\section{Results}

\section{RAGE expression in various rat tissues}

Western blot analysis showed that RAGE was highly expressed in the lung compared to other rat tissues. Untreated rats $(n=3)$ were sacrificed and soluble tissue homogenates were prepared from various organs for the analysis of RAGE by Western blotting (Figure 1).
A

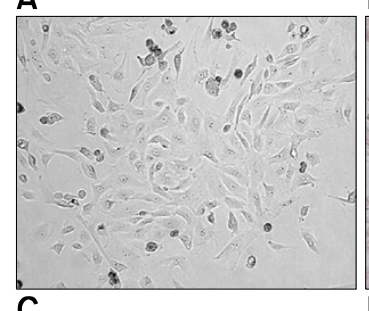

B

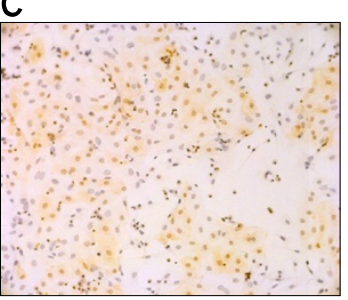

D
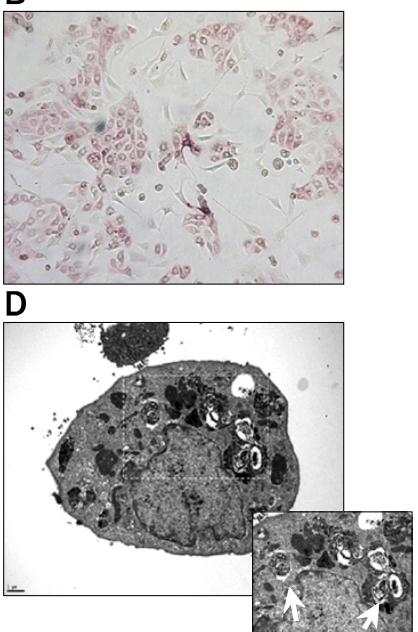

Figure 2. Characteristics of rat alveolar type II epithelial cells and expression of RAGE. (A) Phase-contrast micrographs after seeding isolated rat alveolar type II epithelial cells (magnification $\times 400$ ). (B) Alveolar type II epithelial cells were stained with alkaline phosphatase (magnification $\times 400$ ). (C) A lot of alveolar type II epithelial cells were stained with an antibody to RAGE (magnification $\times 200$ ). (D) Electron micrograph of isolated alveolar type II epithelial cells (magnification $\times$ 10,000).

\section{Characteristics of rat primary ATII cells}

Alkaline phosphatase is an ATII cell marker in the lung (Edelson et al., 1988). Isolated primary ATII cells showed strong positive staining for alkaline phosphatase (pink) in the cytoplasm. These cells were also stained with anti-RAGE antibodies (Figure 2). In most of the cells, lamellar bodies, which are a characteristic feature of ATII cells, were clearly observed by electron microscopy (Figure 2).

\section{AGEs inhibits the TGF- $\beta$-induced EMT}

The de novo expression of $\alpha$-SMA and loss of E-cadherin have been used as markers of the EMT (Li et al., 2004; Kasai et al., 2005; Willis et al., 2005). As shown in Figure 3, AGE alone had no effect on $\alpha$-SMA or E-cadherin mRNA expression at $24 \mathrm{~h}$. As expected, TGF- $\beta$ increased $\alpha$-SMA mRNA expression and decreased E-cadherin mRNA expression. The addition of AGE inhibited the TGF$\beta$-induced EMT in terms of $\alpha$-SMA and E-cadherin mRNA expression. The addition of RAGE siRNA blocked the inhibitory effect of AGE on the TGF- $\beta$ induced EMT, and the addition of neutralizing anti-TGF- $\beta$ antibodies also blocked the TGF- $\beta$-induced EMT. These findings were confirmed by Western blot analysis and two-color immunocytochemistry as shown in Figures 4 and 5 . Indeed, the addition of AGE decreased TGF- $\beta$-induced $\alpha$-SMA protein expression and increased TGF- $\beta$-induced E-cad- 

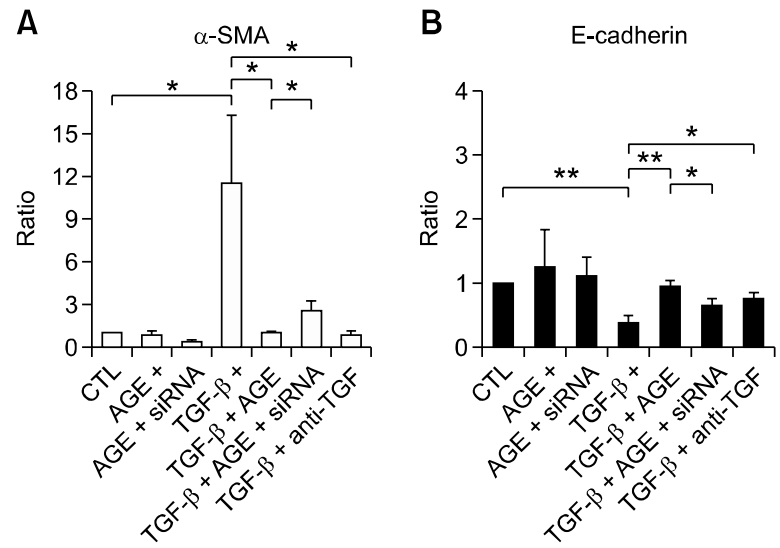

Figure 3. Quantitative real time RT-PCR analysis of $\alpha$-SMA and E-cadherin in rat alveolar type II epithelial cells. Total RNA was isolated from epithelial cells in each treatment group and subjected to quantitative RT-PCR using a iQ5 cycler instrument. The mean point for the $\alpha$-SMA and $\mathrm{E}$-cadherin product was normalized to that of the housekeeping gene glyceraldehyde-3-phosphate dehydrogenase (GAPDH). Advanced glycation end product (AGE) alone had no effect on the epithelial-mesenchymal transition (EMT) but decreased the TGF- $\beta$-mediated EMT; decreased the $\alpha$-SMA mRNA and increased the E-cadherin mRNA. RAGE siRNA transfection reversed the inhibitory effects of AGE on the TGF- $\beta$ mediated EMT. Statistical analysis was performed using student's $t$ test; * $P<0.05,{ }^{* *} P<0.01$.

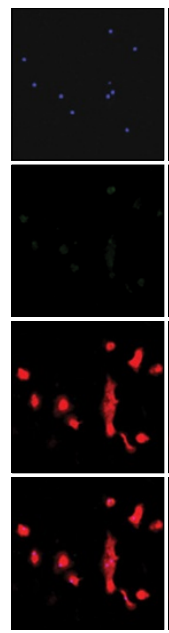

Control

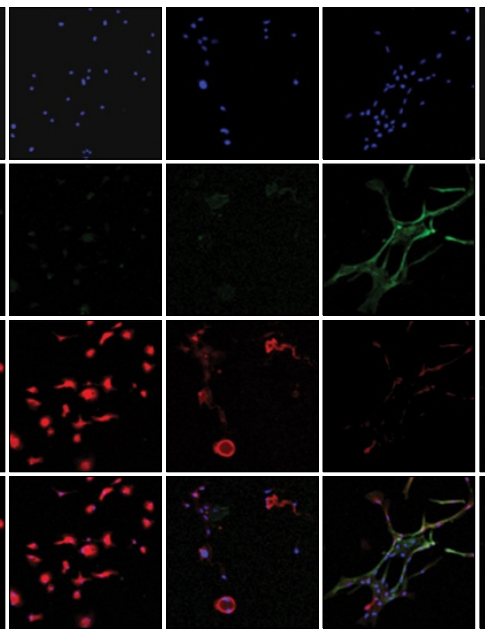

$A G E+\quad A G E+$ siRNA
TGF- $\beta+$

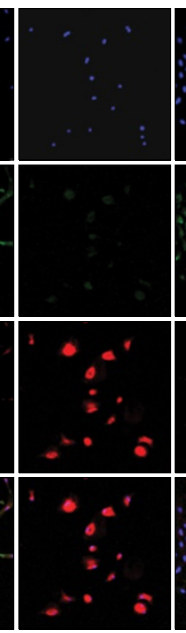

TGF- $\beta+$ AGE

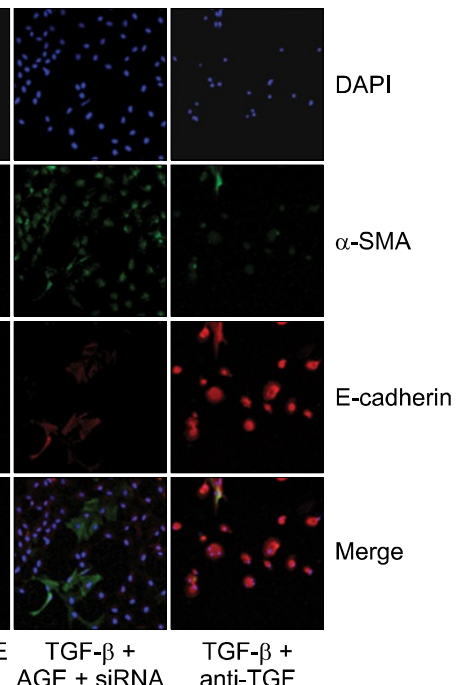

Figure 5. Effects of AGE on alveolar type II cell morphology and expression of $\alpha$-SMA and E-cadherin. Immunoreactivity for $\alpha$-SMA (green) and E-cadherin (red) was assessed by immunofluorescence $72 \mathrm{~h}$ after AGE treatment. Nuclei were stained with DAPI (blue). $\alpha$-SMA was highly expressed in TGF- $\beta$ treated alveolar type II epithelial cells but was disappeared in AGE treatment. E-cadherin expression was decreased by TGF- $\beta$ but was increased by AGE treatment. AGE siRNA transfection reversed these effects of AGE on the TGF- $\beta$-mediated EMT. Results shown are representative of three independent experiments. Original magnification $\times 400$. herin protein expression at $72 \mathrm{~h}$ (Figure 4). The inhibitory effect of AGE on the TGF- $\beta$-induced EMT was also reversed by RAGE siRNA treatment at the protein level. These findings were confirmed by two-color immunocytochemistry (Figure 5).

\section{Effects of AGE on TGF- $\beta$-dependent SMAD-2 phosphorylation and SMAD-7 expression}

As shown in Figure 6, TGF- $\beta$-induced SMAD-2 phosphorylation was suppressed by the addition of $A G E$, and this effect was reversed by RAGE siRNA treatment as shown by Western blot analysis. In contrast, the addition of AGE reversed the TGF- $\beta$ - 


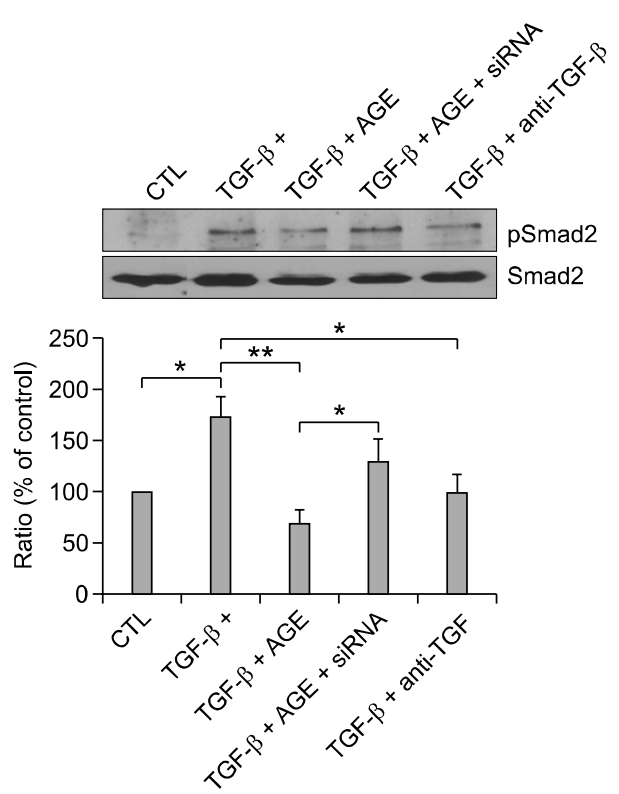

Figure 6. AGE decreased the TGF- $\beta$-mediated Smad2 phosphorylation in rat alveolar type II epithelial cells. Alveolar epithelial cell lysates were subjected to Western blotting using an anti-pSmad2 and total Smad2 antibody. Blots were analyzed by densitometry and the ratios of pSmad2 to Smad2 were compared with control. Statistical analysis was performed using student's $t$ test; ${ }^{*} P<0.05,{ }^{* *} P<0.01$.

dependent suppression of SMAD-7 expression. This effect was also reversed by the addition of RAGE siRNA (Figure 7).

\section{Effects of AGE on TGF- $\beta$-dependent ERK1/2 phosphorylation}

The signaling pathway whereby AGE inhibits the EMT via a TGF- $\beta$-dependent mechanism was also explored. As shown in Figure 8, TGF- $\beta$ induced ERK1/2 phosphorylation, and the addition of AGE inhibited TGF- $\beta$-dependent ERK1/2 MAP kinase signaling. The addition of RAGE siRNA did not block the effect of AGE on TGF- $\beta$-dependent ERK1/2 phosphorylation. In contrast, anti-TGF- $\beta$ antibodies inhibited the TGF- $\beta$-dependent activation of ERK1/2.

\section{Discussion}

In the present study, we demonstrated for the first time that AGE inhibits the TGF- $\beta$-dependent EMT in rat alveolar epithelial cells via its interaction with RAGE. Our findings differ from those in studies of diabetic nephropathy and renal fibrosis (Makita et al., 1991; Vlassara et al., 1994). RAGE is involved in the process of fibrotic change in several organs, including peritoneal fibrosis (Schwenger et al., 2006)

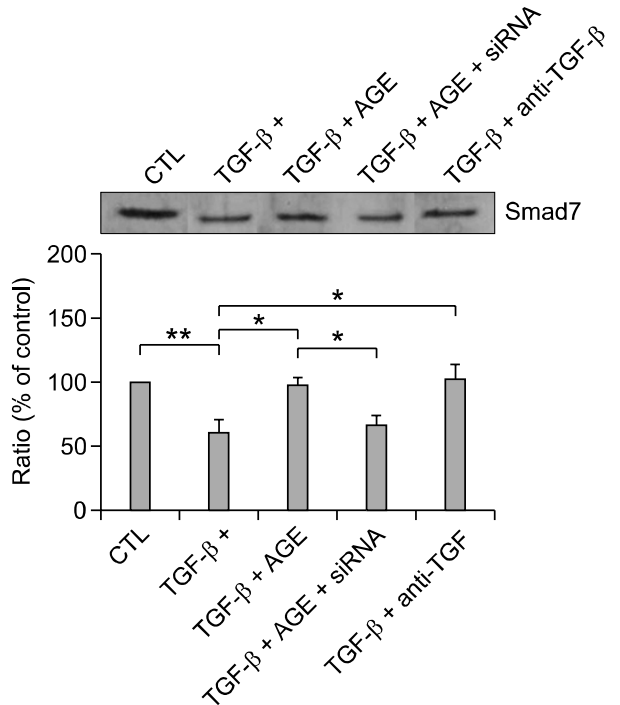

Figure 7. AGE reversed the TGF- $\beta$-mediated down-regulation of Smad7 expression. Alveolar epithelial cell lysates were subjected to Western blotting using an anti-Smad7 antibody. RAGE siRNA reversed the effects of AGE on the TGF- $\beta$ mediated down-regulation of Smad7. Blots were analyzed by densitometry and the expression of Smad7 was compared to control values. Statistical analysis was performed using student's $t$ test; ${ }^{*} P<0.05,{ }^{* *} P<0.01$

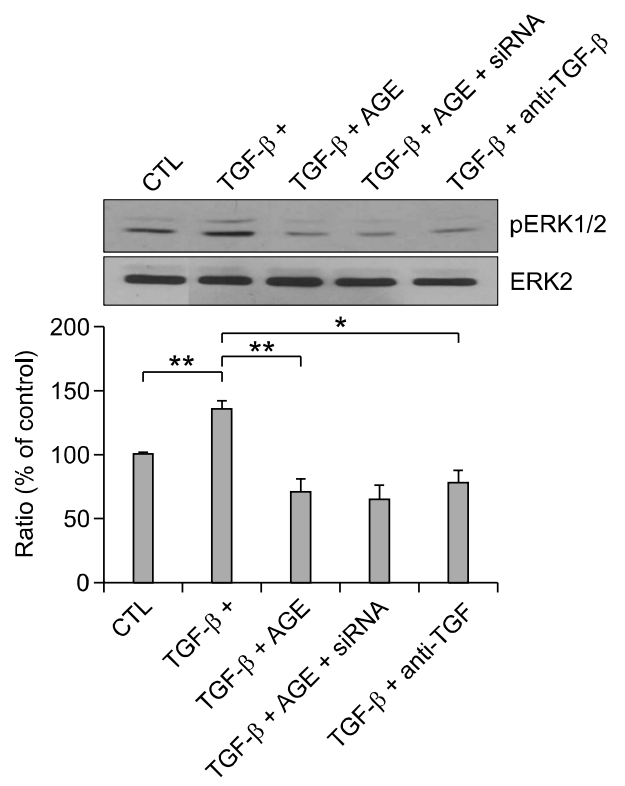

Figure 8. AGE or anti-TGF- $\beta$ antibody inhibited the TGF- $\beta$ mediated ERK1/2 phosphorylation. RAGE siRNA did not reverse the inhibitory effects of AGE on the TGF- $\beta$ mediated ERK $1 / 2$ phosphorylation. Blots were analyzed by densitometry and the ratio of $p E R K 1 / 2$ to ERK $1 / 2$ was compared to control ratio. Statistical analysis was performed using student's $t$ test; ${ }^{*} P<0.05,{ }^{* *} P<0.01$.

and kidney fibrosis (Li et al., 2004; Bohlender et al., 2005). However, the AGE-RAGE interaction in the development of pulmonary fibrosis, especially 
in the area of the EMT, is not clearly understood. RAGE, a receptor for $A G E$, is a multi-ligand receptor on vascular cells that plays a key role in the inflammatory processes (Schmidt et al., 2001) induced by AGE, which accumulates during hyperglycemia and oxidative stress. Moreover, RAGE binds amyloid components, which are characteristic in Alzheimer's disease (Yan et al., 1996), as well as S100/calgranulin family proteins and HMGB1, which have proinflammatory effects (Chavakis et al., 2004).

In this study, we detected significant RAGE expression in normal rat lung tissue, whereas all other major organs exhibited low basal levels of expression. RAGE is constitutively expressed during embryonic development (Oldfield et al., 2001), but its expression is down-regulated in adults except for in the lungs, where it is constitutively expressed (Brett et al., 1993). This observation suggests that RAGE helps protect the lungs from injury. Soluble RAGE (sRAGE) is a soluble isoform of RAGE that lacks a transmembrane domain and is secreted (Malherbe et al., 1999). SRAGE is a decoy molecule due to its ability to bind RAGE ligands and inhibit RAGE signaling. In bleomycin-injured mice, pulmonary SRAGE, which is predicted to have protective effects against inflammatory injury, was not detected (Hanford et al., 2003). A separate study showed the significant down-regulation of RAGE in lung homogenates and ATII cells from patients with IPF, as well as in bleomycin-treated mice (Queisser et al., 2008). These findings conflict with results from previous papers showing that RAGE contributes to bleomycin-induced lung fibrosis (He at al., 2007; Hamada et al., 2008).

The present study showed that the AGE-RAGE interaction inhibited the TGF- $\beta$-induced rat alveolar EMT and was reversed by RAGE siRNA treatment. The transition of alveolar epithelial cells to myofibroblasts in the presence of TGF- $\beta$ strongly suggests that epithelial cells serve as a source of myofibroblasts in pulmonary fibrosis, possibly in response to epithelial cell injury. It is increasingly acknowledged that alveolar epithelial cells undergo the EMT when chronically exposed to TGF- $\beta$ (Willis et al., 2005), and that myofibroblasts constitute fibroblastic foci and are considered to be central to the pathogenesis of IPF. Our results differ from those of previous studies showing that AGE induces the renal tubular epithelial to myofibroblast transition through the RAGE-ERK1/2 MAP kinase pathway (Li et al., 2004). In contrast, we found that AGE inhibited TGF- $\beta$-induced ERK1/2 and SMAD2 phosphorylation, and increased SMAD7 expression, which was suppressed by TGF- $\beta$. TGF- $\beta$ induces the alveolar EMT in human lung epithelial cells via a SMAD2- or SMAD3-dependent pathway (Yao et al., 2004; Kasai et al., 2005; Hackett et al., 2009) and is considered to be an important step toward fibroblastic foci formation in IPF (Thannickal et al., 2004; Gharaee-Kermani et al., 2007). SMAD7 inhibits TGF- $\beta$ signaling through competitive binding to type 1 receptors, and it inhibits the activation of SMAD2/3 (Li et al., 2003). In addition, SMAD7 inhibits $\alpha$-SMA expression in rat lung epithelial cells (Shukla et al., 2009). Our data suggest that AGE inhibited TGF- $\beta$-dependent SMAD2 phosphorylation via SMAD7 activation. As TGF- $\beta$ is a potent inducer of extracellular matrix formation and has been implicated as a key mediator of lung fibrogenesis, the inhibitory effect of AGE on TGF- $\beta$-induced ERK1/2 MAPK and SMAD2 phosphorylation is interesting. Although many other reports indicate that RAGE signaling is important in the pathophysiology of non-pulmonary and certain pulmonary diseases, we found that RAGE signaling through AGE inhibited the EMT and TGF- $\beta$-induced SMAD2 phosphorylation in rat alveolar epithelial cells by SMAD7 activation.

The present study has certain limitations, the most important being that we did not use other primary epithelial cells, such as renal tubular epithelial cells, which have been extensively studied in the tubular EMT in diabetic nephropathy, concomitantly with alveolar epithelial cells. Further, we did not study the underlying mechanism of how AGE elevates SMAD7 expression in rat alveolar epithelial cells. Notwithstanding these limitations, our findings suggest that the basal high level of RAGE expression in the lungs plays an important protective role in the development of pulmonary fibrosis by inhibiting the TGF- $\beta$-induced EMT.

\section{Methods}

\section{Preparation of AGE-BSA protein}

AGE-BSA was prepared according to a modified version of a previously described protocol (Valcourt et al., 2007). BSA ( $50 \mathrm{mg} / \mathrm{ml}$; Fraction V, Sigma, St. Louis, MO) was incubated with $0.6 \mathrm{M} \mathrm{D}$-ribose and incubated at $37^{\circ} \mathrm{C}$ for one week in phosphate-buffered saline (PBS) containing $100 \mathrm{U} / \mathrm{ml}$ penicillin and $100 \mu \mathrm{g} / \mathrm{ml}$ streptomycin. Unincorporated sugars were removed using PD-10 desalting columns (GE Healthcare, Uppsala, Sweden).

\section{ATIl cell isolation and characterization}

ATIl cells were isolated from seven-week-old male SpragueDawley (SD) specific pathogen-free rats as described previously (Richards et al., 1987). Primary rat ATII cells were plated onto Petri dishes to avoid contamination with fibro- 
blasts, macrophages, and neutrophils. After incubation for $1 \mathrm{~h}$, the cells were resuspended in DMEM medium supplemented with $10 \%$ FBS, $100 \mathrm{U} / \mathrm{ml}$ penicillin, and $100 \mu \mathrm{g} / \mathrm{ml}$ streptomycin.

\section{RNA interference and transfection}

The isolated ATII cells were transfected with RAGE siRNA (Santa Cruz Biotechnology, Santa Cruz, CA) according to the manufacturer's instructions. Cells were grown to confluence without antibiotics and treated with $80 \mu \mathrm{mol}$ of RAGE siRNA for $7 \mathrm{~h}$ at $37^{\circ} \mathrm{C}$. The cells were washed with $2 \times$ normal growth medium containing antibiotics then incubated in $1 \times$ normal growth medium for $72 \mathrm{~h}$.

\section{Cell culture}

ATII cells were used ten days after being isolated. Each group was pre-treated with RAGE siRNA or anti-TGF- $\beta$ (10 $\mu \mathrm{g} / \mathrm{ml}$ ) for the RAGE inhibition study, and then stimulated with AGE $(200 \mu \mathrm{g} / \mathrm{ml})$ or TGF- $\beta(10 \mathrm{ng} / \mathrm{ml})$. All cells were cultured in DMEM medium supplemented with $10 \%$ FBS, $100 \mathrm{U} / \mathrm{ml}$ penicillin, and $100 \mu \mathrm{g} / \mathrm{ml}$ streptomycin at $37^{\circ} \mathrm{C}$ in a humidified $5 \% \mathrm{CO}_{2}$ water-jacketed incubator.

\section{Alkaline phosphatase staining and morphological analysis of rat ATII cells}

The ATII cell phenotype was confirmed by alkaline phosphatase staining as described previously (Witherden et al., 2004) followed by transmission electron microscopy. Cells were fixed with $4 \%$ paraformaldehyde and stained with naphthol/fast red violet solution for $15 \mathrm{~min}$ at room temperature according to the manufacturer's protocol (Millipore, Billerica, MA). Positive cells appeared dark pink by light microscopy. To visualize the ATII cell structure and lamellar bodies, cells were fixed with glutaraldehyde and observed by transmission electron microscopy.

\section{Immunocytochemistry for RAGE, $\alpha$-SMA, and E-cadherin}

Cultured ATII cells were fixed with $2 \%$ paraformaldehyde in PBS. For RAGE immunostaining, cells were incubated with anti-RAGE antibodies (1:200; Santa Cruz Biotechnology) at $4^{\circ} \mathrm{C}$ overnight. The colorimetric reaction was developed with 3,3'-diaminobenzidine tetrachloride (Zymed Laboratory Inc., South San Francisco, CA). For the EMT study, cells were fixed with $2 \%$ paraformaldehyde and then double-stained with antibodies against $\alpha$-SMA and E-cadherin (1:50, Santa Cruz Biotechnology). Positive cells were observed by confocal microscopy.

\section{Real time RT-PCR for $\alpha$-SMA and E-cadherin}

ATII cells were harvested $24 \mathrm{~h}$ after stimulation with AGE. RNA was extracted using TRIZOL reagent (Invitrogen, Carlsbad, CA) and then reverse-transcribed into cDNA. The cDNA was amplified in an iQ5 cycler (Bio-Rad,
Hercules, CA) with SYBR Green Real-Time Premix (RBC Bioscience, Chung Ho City, Taiwan) using specific primer pairs ( $\alpha$-SMA: 5'-CGGGCTTTGCTGGTGATG-3' / 5'-GGT CAGGATCCCTCTCTTGCT-3'; E-cadherin: 5'-GGCCCAG GAGCTGACAAAC-3' / 5'-CCAGAGGCTGCGTCACTTTC-3'). The cycling conditions were 45 cycles at $60^{\circ} \mathrm{C}$. The amount of product was normalized with glyceraldehyde-3-phosphate dehydrogenase (GAPDH: 5'-CAACTCCCTCAAGATTGTCA GCAA-3' / 5'-GGCATGGACTGTGGTCATGA-3').

\section{Western blotting}

Brain, heart, lung, liver, and kidney tissues were collected from SD rats (seven-week-old males) and disrupted with RIPA buffer by homogenization. The isolated ATII cells were destroyed in RIPA buffer $(50 \mathrm{mM}$ Tris- $\mathrm{HCl}, 150 \mathrm{mM}$ $\mathrm{NaCl}, 0.1 \%$ SDS, $1 \% \mathrm{NP}-40$, and $0.5 \%$ deoxycholic acid, $\mathrm{pH} 7.5)$ on ice for $30 \mathrm{~min}$. The proteins $(50 \mu \mathrm{g})$ extracted from the different tissues or ATIl cells were quantified by the Bradford method and subjected to Western blot analysis using the following antibodies: anti-RAGE, anti- $\alpha-S M A$, anti-E-cadherin, anti-ERK, anti-SMAD-2 (1:200, Santa Cruz Biotechnology), anti-SMAD-7 (1:500, R\&D Systems, Minneapolis, MN), and anti- $\beta$-actin (1:50,000, Sigma).

\section{Statistical analysis}

All values are expressed as the mean \pm SEM from at least three independent experiments. Differences between the control and experimental groups were compared using Student's $t$-test (SPSS version 10.0.7, SPSS Inc., Chicago, IL). Results were considered statistically significant at $P<$ 0.05 .

\section{Acknowledgements}

The present study was supported in part by grants from the College of Medicine, the Catholic University of Korea.

\section{References}

Bargagli E, Penza F, Bianchi N, Olivieri C, Bennett D, Prasse A, Rottoli P. Controversial role of RAGE in the pathogenesis of idiopathic pulmonary fibrosis. Resp Physiol Neurobiol 2009;165:119-20; author reply 121-2

Bohlender JM, Franke S, Stein G, Wolf G. Advanced glycation end products and the kidney. Am J Physiol Renal Physiol 2005;289:F645-59

Brett J, Schmidt AM, Yan SD, Zou YS, Weidman E, Pinsky D, Nowygrod R, Neeper M, Przysiecki C, Shaw A, et al. Survey of the distribution of a newly characterized receptor for advanced glycation end products in tissues. Am J Pathol 1993;143:1699-712

Brownlee M, Cerami A, Vlassara H. Advanced glycosylation end products in tissue and the biochemical basis of diabetic complications. N Engl J Med 1988;318:1315-21 
Chavakis T, Bierhaus A, Al-Fakhri N, Schneider D, Witte S, Linn T, Nagashima M, Morser J, Arnold B, Preissner KT, Nawroth PP. The pattern recognition receptor (RAGE) is a counterreceptor for leukocyte integrins: a novel pathway for inflammatory cell recruitment. J Exp Med 2003;198:1507-15

Chavakis T, Bierhaus A, Nawroth PP. RAGE (receptor for advanced glycation end products): a central player in the inflammatory response. Microbes Infect 2004;6:1219-25

Edelson JD, Shannon JM, Mason RJ. Alkaline phosphatase: a marker of alveolar type II cell differentiation. Am Rev Respir Dis 1988;138:1268-75

Englert JM, Hanford LE, Kaminski N, Tobolewski JM, Tan RJ, Fattman CL, Ramsgaard L, Richards TJ, Loutaev I, Nawroth PP, Kasper M, Bierhaus A, Oury TD. A role for the receptor for advanced glycation end products in idiopathic pulmonary fibrosis. Am J Pathol 2008;172:583-91

Gharaee-Kermani M, Gyetko MR, Hu B, Phan SH. New insights into the pathogenesis and treatment of idiopathic pulmonary fibrosis: a potential role for stem cells in the lung parenchyma and implications for therapy. Pharm Res 2007; 24:819-41

Hackett TL, Warner SM, Stefanowicz D, Shaheen F, Pechkovsky DV, Murray LA, Argentieri R, Kicic A, Stick SM, Bai TR, Knight DA. Induction of epithelial-mesenchymal transition in primary airway epithelial cells from patients with asthma by transforming growth factor-beta1. Am J Respir Crit Care Med 2009;180:122-33

Hamada N, Maeyama T, Kawaguchi T, Yoshimi M, Fukumoto J, Yamada M, Yamada S, Kuwano K, Nakanishi Y. The role of high mobility group box1 in pulmonary fibrosis. Am J Respir Cell Mol Biol 2008;39:440-7

Hanford LE, Fattman CL, Shaefer LM, Enghild JJ, Valnickova $Z$, Oury TD. Regulation of receptor for advanced glycation end products during bleomycin-induced lung injury. Am J Resp Cell Mol Biol 2003;29(3 Suppl):S77-81

He M, Kubo H, Ishizawa K, Hegab AE, Yamamoto Y, Yamamoto $H$, Yamaya $M$. The role of the receptor for advanced glycation end-products in lung fibrosis. Am J Physiol Lung Cell Mol Physiol 2007;293:L1427-36

Hofmann MA, Drury S, Fu C, Qu W, Taguchi A, Lu Y, Avila C, Kambham N, Bierhaus A, Nawroth P, Neurath MF, Slattery T, Beach D, McClary J, Nagashima M, Morser J, Stern D, Schmidt AM. RAGE mediates a novel proinflammatory axis: a central cell surface receptor for $\$ 100 /$ calgranulin polypeptides. Cell 1999;97:889-901

Hori O, Brett J, Slattery T, Cao R, Zhang J, Chen JX, Nagashima M, Lundh ER, Vijay S, Nitecki D, et al. The receptor for advanced glycation end products (RAGE) is a cellular binding site for amphoterin. Mediation of neurite outgrowth and co-expression of rage and amphoterin in the developing nervous system. J Biol Chem 1995;270: 25752-61

Huang JS, Guh JY, Chen HC, Hung WC, Lai YH, Chuang LY. Role of receptor for advanced glycation end-product (RAGE) and the JAK/STAT-signaling pathway in AGE-induced collagen production in NRK-49F cells. J Cell Biochem 2001;81:102-13
Kasai H, Allen JT, Mason RM, Kamimura T, Zhang Z. TGFbeta1 induces human alveolar epithelial to mesenchymal cell transition (EMT). Respir Res 2005;6:56

Kislinger T, Fu C, Huber B, Qu W, Taguchi A, Du Yan S, Hofmann M, Yan SF, Pischetsrieder M, Stern D, Schmidt AM. $\mathrm{N}$ (epsilon)-(carboxymethyl)lysine adducts of proteins are ligands for receptor for advanced glycation end products that activate cell signaling pathways and modulate gene expression. J Biol Chem 1999;274:31740-9

Li JH, Wang W, Huang XR, Oldfield M, Schmidt AM, Cooper $\mathrm{ME}$, Lan HY. Advanced glycation end products induce tubular epithelial-myofibroblast transition through the RAGE-ERK1/2 MAP kinase signaling pathway. Am J Pathol 2004;164: 1389-97

Li Y, Yang J, Dai C, Wu C, Liu Y. Role for integrin-linked kinase in mediating tubular epithelial to mesenchymal transition and renal interstitial fibrogenesis. J Clin Invest 2003;112:503-16

Makita Z, Radoff S, Rayfield EJ, Yang Z, Skolnik E, Delaney V, Friedman EA, Cerami A, Vlassara H. Advanced glycosylation end products in patients with diabetic nephropathy. $\mathrm{N}$ Engl J Med 1991;325:836-42

Malherbe P, Richards JG, Gaillard H, Thompson A, Diener C, Schuler A, Huber G. cDNA cloning of a novel secreted isoform of the human receptor for advanced glycation end products and characterization of cells co-expressing cellsurface scavenger receptors and Swedish mutant amyloid precursor protein. Brain Res Mol Brain Res 1999;71:159-70

Morbini P, Villa C, Campo I, Zorzetto M, Inghilleri S, Luisetti $M$. The receptor for advanced glycation end products and its ligands: a new inflammatory pathway in lung disease? Modern Pathol 2006;19:1437-45

Morcos M, Sayed AA, Bierhaus A, Yard B, Waldherr R, Merz W, Kloeting I, Schleicher E, Mentz S, Abd el Baki RF, Tritschler H, Kasper M, Schwenger V, Hamann A, Dugi KA, Schmidt AM, Stern D, Ziegler R, Haering HU, Andrassy M, van der Woude F, Nawroth PP. Activation of tubular epithelial cells in diabetic nephropathy. Diabetes 2002;51:3532-44

Neeper M, Schmidt AM, Brett J, Yan SD, Wang F, Pan YC, Elliston K, Stern D, Shaw A. Cloning and expression of a cell surface receptor for advanced glycosylation end products of proteins. J Biol Chem 1992;267:14998-5004

Oldfield MD, Bach LA, Forbes JM, Nikolic-Paterson D, McRobert A, Thallas V, Atkins RC, Osicka T, Jerums G, Cooper ME. Advanced glycation end products cause epithelial-myofibroblast transdifferentiation via the receptor for advanced glycation end products (RAGE). J Clin Invest 2001;108:1853-63

Queisser MA, Kouri FM, Konigshoff M, Wygrecka M, Schubert U, Eickelberg O, Preissner KT. Loss of RAGE in pulmonary fibrosis: molecular relations to functional changes in pulmonary cell types. Am J Respir Cell Mol Biol 2008;39:337-45

Richards RJ, Davies N, Atkins J, Oreffo VI. Isolation, biochemical characterization, and culture of lung type II cells of the rat. Lung 1987;165:143-58

Schmidt AM, Vianna M, Gerlach M, Brett J, Ryan J, Kao J, Esposito C, Hegarty H, Hurley W, Clauss M, et al. Isolation 
and characterization of two binding proteins for advanced glycosylation end products from bovine lung which are present on the endothelial cell surface. J Biol Chem 1992; 267:14987-97

Schmidt AM, Yan SD, Yan SF, Stern DM. The biology of the receptor for advanced glycation end products and its ligands. Biochim Biophys Acta 2000;1498:99-111

Schmidt AM, Yan SD, Yan SF, Stern DM. The multiligand receptor RAGE as a progression factor amplifying immune and inflammatory responses. J Clin Invest 2001;108:949-55

Schwenger V. GDP and AGE receptors: mechanisms of peritoneal damage. Contribut Nephrol 2006;150:77-83

Selman M, Pardo A. The epithelial/fibroblastic pathway in the pathogenesis of idiopathic pulmonary fibrosis. Am J Respir Cell Mol Biol 2003;29(3 Suppl):S93-7

Shukla MN, Rose JL, Ray R, Lathrop KL, Ray A, Ray P. Hepatocyte growth factor inhibits epithelial to myofibroblast transition in lung cells via Smad7. Am J Respir Cell Mol Biol 2009;40:643-53

Thannickal VJ, Toews GB, White ES, Lynch JP 3rd, Martinez FJ. Mechanisms of pulmonary fibrosis. Ann Rev Med 2004; 55:395-417

Valcourt U, Merle B, Gineyts E, Viguet-Carrin S, Delmas PD, Garnero P. Non-enzymatic glycation of bone collagen modifies osteoclastic activity and differentiation. J Biol Chem 2007;282:5691-703
Vlassara H, Bucala R, Striker L. Pathogenic effects of advanced glycosylation: biochemical, biologic, and clinical implications for diabetes and aging. Lab Invest 1994;70: 138-51

Willis BC, Liebler JM, Luby-Phelps K, Nicholson AG, Crandall ED, du Bois RM, Borok Z. Induction of epithelial-mesenchymal transition in alveolar epithelial cells by transforming growth factor-beta1: potential role in idiopathic pulmonary fibrosis. Am J Pathol 2005;166:1321-32

Witherden IR, Vanden Bon EJ, Goldstraw P, Ratcliffe C, Pastorino U, Tetley TD. Primary human alveolar type II epithelial cell chemokine release: effects of cigarette smoke and neutrophil elastase. Am J Respir Cell Mol Biol 2004; 30:500-9

Yan SD, Chen X, Fu J, Chen M, Zhu H, Roher A, Slattery T, Zhao L, Nagashima M, Morser J, Migheli A, Nawroth P, Stern $D$, Schmidt AM. RAGE and amyloid-beta peptide neurotoxicity in Alzheimer's disease. Nature 1996;382:685-91

Yao HW, Xie QM, Chen JQ, Deng YM, Tang HF. TGF-beta1 induces alveolar epithelial to mesenchymal transition in vitro. Life Sci 2004;76:29-37

Yeh CH, Sturgis L, Haidacher J, Zhang XN, Sherwood SJ, Bjercke RJ, Juhasz O, Crow MT, Tilton RG, Denner L. Requirement for p38 and p44/p42 mitogen-activated protein kinases in RAGE-mediated nuclear factor-kappaB transcriptional activation and cytokine secretion. Diabetes 2001;50:1495-504 